\title{
The Perceived Usefulness of ESG Indicators by Tunisian Financial Professionals: Exploratory Study for the Construction of a Measurement Scale
}

\author{
Souhir KHEMIR \\ Associate Professor \\ University of Haute-Alsace \\ CREGO - UHA (EA 7317) \\ France
}

\begin{abstract}
This research is part of current research on the use of non-financial information. Its objective is to evaluate the perceived usefulness of Environmental, Social and Governance (ESG) indicators, proposed by the Global Reporting Initiative (GRI). A questionnaire survey was conducted among a sample of 105 Tunisian financial professionals. The results show levels of perceived usefulness quite different. Thus, corporate governance dimension collects the highest degree of perceived usefulness, followed by environmental and social ones. With regard to the exploratory factor analyzes, the results revealed a scale composed of 53 ESG indicators adapted to the information needs of Tunisian financial professionals.
\end{abstract}

Keywords: Usefulness, ESG indicators, GRI guidelines, Investment allocation decision, Tunisian financial professionals.

\section{Introduction}

Today, more and more companies are engaging in a Corporate Social Responsibility (CSR) approach. Environmental, Social and Governance (ESG) communication is the most concrete form of this commitment. According to The KPMG Survey of Corporate Responsibility Reporting (2015), more than 90\% of the 250 largest global corporations (G250) and nearly three quarters of the top 100 national companies (N100) report environmental and social information. This communication offers a more global vision of performance, going beyond accounting and financial one.

The desire to facilitate corporate ESG communication practices has led to the emergence of several initiatives aimed at proposing a standardization of practices. Among these initiatives, that of the Global Reporting Initiative (GRI) tends to prevail, particularly because of the richness of its content (McGraw and Katsouras, 2010). But this wealth, which is materialized by the large number of indicators proposed, can also be a source of problems or at least of choices to be made by the companies wishing to adopt them to organize their communication. Indeed, the question of the utility for the investor of each of the proposed indicators remains open and may require a prioritization.

In this context, the question of the usefulness of ESG information as a complement to financial information arises, particularly from the point of view of the potential investor. Although, in the past, financial information was the main source for investment decisions, it is the subject of criticism, in particular because of its orientation towards the past and the fact that it does not provide a clear vision on the future performance of the company (Cauvin et al., 2006). Sahut and Pasquini-Descomps (2015) consider that the question of how and why investorstake into account CSR activities when making investment decisions is very relevant.

In Tunisia, ESG is becoming a growing concern (Ben Rhouma et al., 2011). The numerous reforms initiated in favor of CSR constitute a real incentive for companies to engage in a socially responsible approach. However, corporate communication practices appear to be reduced (Khemir and Baccouche, 2010). According to Frimousse et al. (2006), unlike financial communication, social communication of Tunisian companies seems marginal. Chakroun (2012) has shown that voluntary disclosure policy in the annual reports of Tunisian companies is considered by financial analysts to be minimalist. 
Although it has foreseen the possibility of the communication of ESG information, Tunisian accounting system, in its conceptual framework, has specified neither its content nor its form. This seems to be an obstacle for companies wishing to communicate their performance in the ESG areas.

Most research conducted in this country has focused on the analysis of ESG communication (Frimousse et al., 2006), the identification of its explanatory factors (Baccouche et al., 2010, Khemir and Baccouche, 2010, Zramdini, 2011), and the assessment of its influence on credit granting and investment decisions (Zramdini and Fedhila, 2003, Khemakhem and Turki, 2007). To our knowledge, no research has focused on the development of a measurement scale or indicators that are tailored to the informational needs of stakeholders. However, it is quite common for financial actors to express dissatisfaction with the extra-financial communication practices of Tunisian companies (Khemir, 2014). This leads us to think about how ESG communication can now be conceptualized and apprehended, in order to contribute to the implementation of a useful reference framework for companies.

The objective of this research is therefore to evaluate the perceived usefulness of the ESG indicators, proposed by the GRI, by Tunisian financial professionals to their investment decision and to develop a measurement scaleof ESG communication adapted to their needs.

Conducting such research in the Tunisian context reflects our desire to explore a context in which consciousness in this field is developing, a context that remains little explored by researchers interested in ESG dimensions. This research enriches the literature on emerging countries and provides information on the value of ESG indicators for Tunisian investors, in the absence of universal standard on the communication of these indicators. It is likely to help reflection on the improvement of standardization and the establishment of a regulatory framework to improve practice. The contribution of this research lies in the analysis of the perceived usefulness of ESG indicators derived from the GRI guidelines and the development of a measurement scale of ESG communication. This is likely to inform companies about the ESG indicators that are most useful for financial professionals and to push them to take them into account in order to provide ESG information that can be used to make investment decisions.

If the guidelines proposed by the GRI have already been analyzed by research from the point of view of the information provider (Henderson et al., 2006), no research adopting the viewpoint of the receiver has been made to our knowledge. However, the question of the usefulness of the information for the users seems to us fundamental in the choice of CSR communication. Our research is therefore in line with studies on the usefulness of extra-financial information, more specifically in the category of survey studies (Milne and Chan, 1999). The rest of this paper is organized as follows: the first section is dedicated to the literature review. The second section describes the research method used to develop a tool for measuring ESG communication. The third section presents the data collection and the results obtained. The fourth section discusses the results and highlights the contributions of this research.

\section{Literature review: the utility and use of ESG information in decision-making}

One of the main objectives of the ESG communication is to meet the growing information needs of the company's stakeholders. Like accounting and financial information, ESG information is supposed to be useful and therefore used, especially, in investment decisions. ESG communication research can be separated into two groups, depending on whether they take the viewpoint of the information provider, or that of the information receiver. Our research belongs to the category of studies adopting the point of view of the information receiver. This type of research focuses on the usefulness of ESG information for all users, whether financial (portfolio managers, financial analysts, credit analysts, etc.) or belonging to other stakeholder's categories (NGOs, consumers, etc.). Empirical studies within this framework adopt a variety of methods and can be classified, according to the method used, into three families: survey studies, reaction studies, and experiments (Milne and Chan, 1999) (see table1). 
Table 1: Typologies of studies on the utility of ESG information to user decision-making

\begin{tabular}{|c|c|c|c|}
\hline & Survey studies & Reaction studies & Experiments \\
\hline Objective & $\begin{array}{l}\text { Identify opinions on the } \\
\text { importance and usefulness of } \\
\text { ESG information }\end{array}$ & $\begin{array}{l}\text { Study the impact of } \\
\text { ESG information on } \\
\text { stock prices }\end{array}$ & $\begin{array}{l}\text { Analyze the influence of ESG } \\
\text { information on individual decision- } \\
\text { making }\end{array}$ \\
\hline $\begin{array}{l}\text { Research } \\
\text { question }\end{array}$ & $\begin{array}{l}\text { What is the perception of ESG } \\
\text { information by stakeholders? }\end{array}$ & $\begin{array}{l}\text { What is the stock } \\
\text { market reaction to ESG } \\
\text { information? }\end{array}$ & $\begin{array}{l}\text { How does ESG information influence } \\
\text { individual decision-making? }\end{array}$ \\
\hline $\begin{array}{l}\text { Research } \\
\text { Examples }\end{array}$ & $\begin{array}{l}\text { Teoh and Shiu (1990), Deegan } \\
\text { and Rankin (1997), Thompson } \\
\text { and Cowton (2004), } \\
\text { Whitehouse (2006), Adams } \\
\text { and Frost (2008), Ioannou and } \\
\text { Serafein (2010), Saghroun and } \\
\text { Eglem (2008), Cohen et al. } \\
\text { (2010), Berry and Junkus } \\
\text { (2013), de Zwaan et al. (2015), } \\
\text { van Duuren et al. (2015). }\end{array}$ & $\begin{array}{l}\text { Lorraine et al. (2004), } \\
\text { Wahba(2008), Kruger } \\
\text { (2009), Guidry and } \\
\text { Patten (2010), Eccles et } \\
\text { al.(2011), Vintilà and } \\
\text { Gherghina (2012), Xu } \\
\text { et al. (2012). }\end{array}$ & $\begin{array}{l}\text { Chan and Milne (1999), Milne and } \\
\text { Chan (1999), Zramdini and Fedhila } \\
\text { (2003), Khemakhem and Turki (2007), } \\
\text { Holm and Rikhardsson (2008), } \\
\text { Rikhardsson and Holm (2008), van der } \\
\text { Laan Smith et al. (2010), Chang and } \\
\text { Wei (2011), Cheng et al. (2015). }\end{array}$ \\
\hline
\end{tabular}

Research concerning the usefulness of ESG information is based on the assumption that while accounting and financial information is provided by companies to serve the information needs of their users, ESG information, too, should play the same role insofar as it is likely to provide information on extra-financial aspects of overall performance. These researches have yielded inconclusive results.

Examining the perception of the importance of CSR information by Australian institutional investors, Teoh and Shiu (1990) have obtained that the latter appreciate the commitment of companies in a CSR approach but consider that the CSR information communicated in annual reports is not important to their investment decisions. In Australia, Deegan and Rankin (1997) have found that shareholders believe that environmental information is important for decision-making while brokers and analysts downplay its importance. Thompson and Cowton (2004) have found that UK bank credit analysts attach importance to the annual report notwithstanding its inadequacy as a source of information on companies' environmental impacts. Whitehouse (2006) has shown that despite the existence of real attempts to develop CSR policies in the UK context, managers state that the context hinders the ability of CSR to provide sufficient information to stakeholders to assess social performance. Adams and Frost (2008) have successfully demonstrated that British and Australian companies integrate environmental and social indicators into their strategic planning, performance determination and risk management decisions. Ioannou and Serafein (2010) have shown that companies engaging in a socially responsible approach are subject to more favorable recommendations by sell-side financial analysts than those who are not. Saghroun and Eglem (2008) have found that environmental and social information is of moderate interest to French financial analysts, and that corporate governance is the preferred topic compared to environmental and social ones. Cohen et al. (2010) have revealed that information about economic performance ranks first in terms of importance for retail investors' investment choices, while information on corporate governance and on CSR occupy respectively second and third place. Berry and Junkus (2013) have found that environmental dimension appears to be the main dimension associated with Social Responsibility Investment (SRI)for socially responsible investors and mainstream ones. Then come questions about company policy and company products. de Zwaan et al. (2015) have sought to examine the perception of ESG investment of Australian pension fundsby their members and have found that the majority of pension fund members are interested in ESG investing. Members show a preference for examining governance issues compared to social and environmental ones and perceive that corporate governance should have a positive impact on financial performance.van Duuren et al. (2015) have conducted an international survey of American and European conventional investment fund managers to analyze how ESG factors are integrated into their investment practices. The results reveal that many conventional fund managers are integrating responsible investing into their investment processes, and consider that governance considerations are more important compared to environmental and social factors. 
In the British context, Lorraine et al. (2004) have obtained a negative reaction from the financial market as a result of negative environmental disclosure. Kruger (2009) has obtained an abnormal negative return when stakeholders, such as newspapers, non-governmental organizations or regulatory authorities, disclose unfavorable CSR information related to the company under review. Guidry and Patten (2010) did not achieve a significant market reaction following the first publication of stand-alone sustainability reports. Eccles et al. (2011) have found that the financial market places a high value on corporate performance and ESG policies, and have demonstrated that at the international level, environmental and corporate governance information are of greater interest to the investors compared to social information. Vintilà and Gherghina (2012) have concluded that American investors use corporate governance ratings to identify and quantify the risks associated with their investments.

The results obtained from Holm and Rikhardsson (2008) study, carried out in the Danish context, prove that, whatever the investment horizon, environmental information has a positive influence on investment decisions. Rikhardsson and Holm (2008) have confirmed that environmental communication has more influence on longterm decisions and that qualitative environmental information affects short-term investment decisions.

Analyzing four countries, namely: United States, Japan, France and Sweden, van der Laan Smith et al. (2010) have shown that CSR disclosure has a significant impact on investor behavior. Chang and Wei (2011) have demonstrated that strength governance affects investment decision, concluding that investors are willing to pay more for companies with a strong governance system. More recently, Cheng et al. (2015) have shown that investors are more willing to invest in companies whose ESG indicators are of high strategic relevance.

Like developed countries, some research have analyzed the use of CSR communication in emerging countries. Conducting a reaction study in the Egyptian context, Wahba (2008) has shown that the financial market rewards companies that adopt an environmental responsibility strategy. The results of the study by Xu et al. (2012) reveal that communication about environmentally harmful events by Chinese listed companies has a small impact on the stock market. Chen et al. (2003) have found that investing in a well-respected corporate governance firm is likely to generate an average of $8.5 \%$ of abnormal return and have pointed out that corporate governance communication does not play an important role in reducing information asymmetry in emerging equity markets such as the Asian one. In Tunisia, few studies have analyzed ESG communication by positioning themselves on the side of the information receiver (Zramdini and Fedhila, 2003, Khemakhem and Turki, 2007). Through their study, Zramdini and Fedhila (2003) have demonstrated that societal information is perceived as being useful for lending decision in a long-term perspective, especially when presented under a quantitative form and published by an independent agency. Khemakhem and Turki (2007) have concluded that environmental information affects the investment decision in the Tunisian context, since the least environmentally performing company loses $13 \%$ of the investment and the best-performing one has an investment increase of $22 \%$.

As we can see, most studies have been realized in developed countries: The United States (Eccles et al., 2011), Great Britain (Lorraine et al., 2004; Thompson and Cowton, 2004), France (Saghroun and Eglem, 2008), Denmark (Holm and Rikhardsson, 2008; Rikhardsson and Holm, 2008), etc. In recent years, there has been a marked interest in favor of CSR in emerging countries. We believe that it is interesting to analyze ESG communication within these countries. Also, the majority of research dealt with one dimension of ESG information: either the environmental dimension or the social one. In this research, we propose to take into account all three dimensions at once. Focusing on one dimension can be problematic as ESG issues are increasingly seen as interconnected (Galbreath, 2013). Thus, compared to the previous literature, we broaden the scope of the extra-financial dimensions studied by including the corporate governance dimension and using the GRI guidelines.

Internationally, the GRI guidelines remain the best known for improving corporate environmental and social communication. They are considered to be the main international standardization initiative for environmental and social reporting (Quairel, 2004) and are intended for use by all companies regardless of their sector of activity and location. The version used in this research isthe G3.1 version which was published in March 2011. This is the update of the G3 version. GRI reviews and updates its guidelines to meet the requirements of stakeholders, including financial professionals who are considered as the main users of information provided by companies. For this reason, we believe that it is important to test the perceived usefulness of the indicators, proposed by the GRI, by financial users of information. 
This stems from the fact that corporate communication practices must take into account the preferences of users of information. In fact, according to the decision-usefulness information theory, the information communicated by companies must be useful from the point of view of the users (Staubus, 1999). The question of the usefulness of GRI's indicators for financial users of information has not yet been addressed in the academic literature. It seems important to us to ask the question of its usefulness for financial users in the framework of a scientific study carried out by an independent researcher.

\section{Research method}

\section{Objectives and content of the questionnaire}

In order to assess the perceived usefulness of ESG indicators derived from the GRI guidelines by Tunisian financial professionals, we have administered a questionnaire structured in two parts. The first part aims to collect the perceived utility of ESG indicators. It includes 94 indicators associated with the Environmental (30 indicators), Social (45 indicators) and Corporate Governance (19 indicators) dimensions. The perceived usefulness of each indicator was measured by a Likert scale ranging from 1 "not useful" to 5 "very useful". The second part of the questionnaire includes questions about the demographic characteristics of the respondent (age, seniority, etc.).

The first version of this questionnaire was pre-tested with 10 financial professionals in order to improve the wording of the questions and to avoid problems of comprehension and ambiguity.

\section{Target population and method of data collection}

The target population is made up of Tunisian financial professionals: financial analysts (sell-side and buy-side) and portfolio managers. The choice of this category of stakeholders is justified by the fact that it has some expertise in the analysis of financial information. Due to lack of time or experience, investors can use the recommendations of financial analysts to make the best investment decisions (Galanti, 2006).

We have chosen to administer our research questionnaire electronically. A website has been created for this purpose. The website presented the questionnaire as well as detailed explanations for each indicator. Initially, a total of 122 Tunisian financial professionals working in stock exchange brokerage firms, management companies, banks and insurance companies were contacted by telephone to solicit their participation in our research and to ask them for their e-mail addresses. In a second time, an email was sent to people who agreed to participate in our research to direct them to the website so that they can complete the questionnaire. 17 emails were returned as undelivered. In the end, the target sample was therefore composed of 105 individuals.

\section{Answers collected}

A total of 62 responses were collected, representing a response rate of approximately 59\%. Table 2 presents the main demographic characteristics of the respondents.

Table 2: Demographic Characteristics of Respondents

\begin{tabular}{|l|l|l|}
\hline Sex & Man & $69 \%$ \\
& Woman & $31 \%$ \\
\hline \multirow{4}{*}{ Age } & $25-35$ years & $52 \%$ \\
& $36-45$ years & $34 \%$ \\
& $46-55$ years & $11 \%$ \\
& 56 years and more & $3 \%$ \\
\hline \multirow{5}{*}{ Diploma } & Licence & $3 \%$ \\
& Mastery & $16 \%$ \\
& DESS & $5 \%$ \\
& DEA/Master & $68 \%$ \\
\multirow{3}{*}{ Job } & Other & $8 \%$ \\
& Financial analyst & $53 \%$ \\
\multirow{2}{*}{ Seniority in the job } & Portfolio Manager & $30 \%$ \\
& Other & $17 \%$ \\
\hline \multirow{2}{*}{ Seniority in the profession } & Average & 6,5 years \\
& Standard deviation & 4,8 years \\
\hline & Average & 7,7 years \\
& Standard deviation & 5,4 years \\
\hline
\end{tabular}




\section{Results}

We first present the results relating to the perceived utility of ESG indicators for investment decision. Secondly, we present the results of the exploratory factor analyze carried out on the collected data.

\section{Perceived utility of ESG indicators}

We present here the perceived usefulness of different categories relating to the ESG dimensions by Tunisian financial professionals, by calculating an average score for each of the categories as well as the subcategories in question.

Indicators related to the environmental dimension

Table 3 presents the average scores obtained for each of categories of environmental information.

\section{Table 3: Perceived utility of Environmental information categories}

\begin{tabular}{|l|r|}
\hline \multicolumn{1}{|c|}{ Environmental information categories } & Average score \\
\hline Materials (1 and 2) & 3,72 \\
\hline Energy (3 to 7) & 3,85 \\
\hline Water (8 to 10) & 3,35 \\
\hline Biodiversity (11 to 15) & 3,20 \\
\hline Emissions, effluents and waste (16 to 25) & 3,59 \\
\hline Products and services (26 and 27) & 3,70 \\
\hline Compliance (28) & 3,97 \\
\hline Transport (29) & 3,31 \\
\hline Overall (30) & 4,02 \\
\hline Total Environmental information categories (1 to 30) & $\mathbf{3 , 5 8}$ \\
\hline
\end{tabular}

The categories of environmental information considered as most useful by the respondents to their investment decisions are those relating to total environmental protection expenditures and investments by type (aspect: overall), compliance and energy with average scores of 4,02; 3,97 and 3,85.

Indicators related to the social dimension

Table 4 shows the average scores obtained for each of the categories and subcategories of social information.

\section{Table 4: Perceived utility of Social information categories and subcategories}

\begin{tabular}{|c|c|}
\hline Social information categories and subcategories & Average score \\
\hline Employment (31 to 34) & 3,56 \\
\hline Labor/ Management relations (35 and 36) & 3,48 \\
\hline Occupational health and safety (37 to 40) & 3,58 \\
\hline Training and education (41 to 43 ) & 3,80 \\
\hline Diversity and equal opportunity (44) & 3,31 \\
\hline Equal remuneration for women and men (45) & 3,25 \\
\hline Total Labor Practices and Decent Work category (31 to 45) & $\mathbf{3 , 5 7}$ \\
\hline Investment and procurement practices (46 to 48 ) & 2,83 \\
\hline Non-discrimination (49) & 3,13 \\
\hline Freedom of association and collective bargaining (50) & 3,07 \\
\hline Child labor (51) & 3,65 \\
\hline Forced and compulsory labor (52) & 3,46 \\
\hline Security practices (53) & 3,20 \\
\hline Indigenous rights (54) & 3,26 \\
\hline Assessment (55) & 2,91 \\
\hline Remediation (56) & 3,21 \\
\hline Total Human Rights category (46 to 56) & 3,13 \\
\hline Local communities (57 to 59) & 3,14 \\
\hline Corruption (60 to 62$)$ & 3,75 \\
\hline Public Policy (63 and 64) & 3,18 \\
\hline Anti-Competitivebehavior (65) & 3,90 \\
\hline Compliance (66) & 4,07 \\
\hline Total Society category (57 to 66) & $\mathbf{3 , 5 1}$ \\
\hline Customer health and safety (67 and 68) & 3,57 \\
\hline Product and service labeling (69 to 71) & 3,71 \\
\hline Marketing communications (72 and 73) & 3,73 \\
\hline Customer privacy (74) & 3,36 \\
\hline Compliance (75) & 3,76 \\
\hline Total Product Responsibility category (67 to 75) & 3,71 \\
\hline Total Social information categories and subcategories ( 31 to 75 ) & 3,47 \\
\hline
\end{tabular}


According to survey participants, the category of product responsibility ranks first in terms of utility for investment decision with an average score of 3,71. It is closely followed by labor practices and decent work with an average score of 3,57. The Human Rights category ranks last with an average score of 3,13.

Indicators related to the corporate governance

Table 5 shows the average scores obtained for each of the categories of corporate governance information.

Table 5: Perceived utility of Corporate Governance information categories

\begin{tabular}{|l|r|}
\hline \multicolumn{1}{|c|}{ Corporate Governance information categories } & \multicolumn{1}{c|}{ Average score } \\
\hline Board of directors structure (76 to 81) & 3,97 \\
\hline Board of directors working (82 to 87) & 4,19 \\
\hline Executive compensation (88 and 89) & 4,07 \\
\hline Statutory auditor (90 and 91) & 4,09 \\
\hline Companyownership structure (92 and 93) & 4,56 \\
\hline Diverse (94) & 3,95 \\
\hline Total Corporate Governance information categories (76 to 94) & $\mathbf{4 , 1 2}$ \\
\hline
\end{tabular}

The participants appear to be mainly interested in company's ownership structure indicators $(4,56)$, board of directors working $(4,19)$ and statutory auditor $(4,09)$.

\section{Results of exploratory factor analyzes}

We present in the following the results of our exploratory factor analyzes. For each of categories and subcategories of ESG indicators, our analysis was conducted in three steps. The first step is to verify the factorization of the data by calculating the KMO index and the Bartlett's test. Then, an exploratory factor analysis is conducted to reduce the number of indicators in factors. The scales relating to each of the $\mathrm{E}, \mathrm{S}$ and $\mathrm{G}$ dimensions were purified by performing principal component analyzes under SPSS, with Varimax rotation. Finally, in a third step, we have determined the internal reliability coefficient (Cronbach's Alpha).

\section{Environmental Scale}

A prior step to the factor analysis is to ensure the correlation of the indicators. Such a correlation conditions the fact that the data are factorizable. The examination of table 6 shows that the KMO index and the Bartlett's test confirm the indicators correlation by presenting satisfactory results.

In fact, the $\mathrm{KMO}^{1}$ index is equal to 0.851 (greater than 0.7), which reflects a strong correlation between the indicators that can therefore be classified into a reduced number of factors. Bartlett's test ${ }^{2}$ has a chi-square equal to 431,387 with a ddl equal to 66 and a significance level of 0,000 , which allows us to reject the hypothesis according to which the correlations of the variables are equal to zero. The eigenvalues for each factor are also greater than 1 . Thus, our data are correlated and therefore factorizable.

Table 6: Factor analysis of Environmental indicators

\begin{tabular}{|c|c|c|c|c|}
\hline \multirow{2}{*}{ Indicators } & \multirow{2}{*}{ Communalities } & \multicolumn{3}{|c|}{ Factors } \\
\hline & & 1 & 2 & 3 \\
\hline 16_Env_EmmisionsEffluentsWaste_1 & ,938 & ,922 & & \\
\hline 18_Env_EmmisionsEffluentsWaste_3 & ,888 & ,862 & & \\
\hline 19_Env_EmmisionsEffluentsWaste_4 & ,839 & ,830 & & \\
\hline 17_Env_EmmisionsEffluentsWaste_2 & ,818 & ,764 & & \\
\hline 20_Env_EmmisionsEffluentsWaste_5 & ,755 & ,664 & & \\
\hline 7_Env_Energy_5 & ,826 & & ,898 & \\
\hline 2_Env_Materials_2 & ,757 & & ,761 & \\
\hline 8_Env_Water_1 & ,740 & & ,746 & \\
\hline 10_Env_Water_3 & ,783 & & ,716 & \\
\hline 24_Env_EmmisionsEffluentsWaste_9 & 832 & & & ,859 \\
\hline 25_Env_EmmisionsEffluentsWaste_10 & ,842 & & & ,839 \\
\hline 22_Env_EmmisionsEffluentsWaste_7 & ,713 & & &, 723 \\
\hline \multicolumn{2}{|l|}{ Eigenvalues } & 7,288 & 1,398 & 1,044 \\
\hline \multicolumn{2}{|l|}{ Percentage of explained common variance for each factor } & 33,102 & 24,726 & 23,255 \\
\hline \multicolumn{2}{|l|}{ Percentage of explained common variance for the 3 factors } & \multicolumn{3}{|c|}{81,083} \\
\hline \multicolumn{2}{|l|}{ Cronbach Alphafor each factor } & ,940 & ,846 & 848 \\
\hline \multicolumn{2}{|l|}{ Total Cronbach Alpha } & \multicolumn{3}{|c|}{,939 } \\
\hline \multicolumn{2}{|l|}{ KMO index } & \multicolumn{3}{|c|}{,851 } \\
\hline $\begin{aligned} \text { Bartlett's test : } \\
\bullet \quad \text { Chi-square } \\
\bullet \quad \text { Ddl }\end{aligned}$ & & \multicolumn{3}{|c|}{$\begin{array}{c}431,387 \\
66 \\
, 000\end{array}$} \\
\hline
\end{tabular}

${ }^{1}$ Whose vocation is to verify the factoring of data

${ }^{2}$ Which is intended to test the hypothesis of the variable correlation nullity 
After purifying and eliminating indicators with a factorial weight less than 0.5 as well as those belonging to several factors ${ }^{3}$, table 6 shows that the factor solution contains less than the half of the environmental indicators proposed by the GRI. Eighteen indicators among thirty have been eliminated. The twelve indicators selected consist of 7 core indicators (indicators $2,8,16,17,19,20,22)$ and 5 additional indicators $(7,10,18,24,25)$. The factorial solution obtained shows three factorial axes. Our construct is thus multidimensional. The three factorial axes explain more than $81 \%$ of the total variance. This is very satisfying because well over $50 \%$.

The first factor contains indicators 16, 17, 18, 19, and 20 belonging to the Emissions, Effluents and Waste category, covering the company's various emissions, so it can be interpreted as the Emissions axis. The second factor seems to be variegated since it includes indicators belonging to various categories of the environmental dimension, namely: indicator 7 which belongs to the Energy category, indicator 2 which relates to the Materials category and finally indicators 8 and 10 which belong to the Water category. Referring to Evrard et al. (2009, p.412) who recommend to "only keep the factor if we can name it", this second factor could be eliminated as we are unable to name it. The third factor is made up of indicators 22, 24 and 25 belonging to the Emissions, Effluents and Waste category, which are related to the company's waste. Therefore, it may be it may be called Waste.The two factors selected have internal reliability coefficients of 0.940 and 0.848 , both higher than 0.7 , which is the recommended level of acceptability. The Cronbach's Alpha appear high. This means that all indicators selected to reflect the efforts made by companies in the environmental field are coherent and correspond to the informational expectations of financial professionals. Thus, the environmental scaleis composed of eight indicators grouped into two categories: Emissions and Waste.

\section{$\underline{\text { Social scales }}$}

In a second step, we have tested the indicators dedicated to the efforts made by companies in the social field. The social dimension analyzed is multidimensional.

It comprises 45 indicators derived from the G3.1 guidelines of GRI and divided into four categories: Labor Practices and Decent Work, Human rights, Society and Product Responsibility.

\section{Sub-scale relating to Labor Practices and Decent Work category}

In the same way as forenvironmental indicators, we have started the analysis by the calculation of the KMO index and Bartlett's test to ensure the adequacy of the data. From table 7, the KMO index is 0.801 . The Bartlett's test is 203,444 , with a ddl of 28 and a significance level of 0,000 . Communalities vary between 0.653 and 0.831 . Thus, we can accept the results of this factor analysis.

Table 7: Factor analysis ofLabor Practices and Decent Work indicators

\begin{tabular}{|c|c|c|c|}
\hline \multirow{2}{*}{ Indicators } & \multirow{2}{*}{ Communalities } & \multicolumn{2}{|c|}{ Factors } \\
\hline & & 1 & 2 \\
\hline 39_OccHealthSafety_3 & ,782 & ,876 & \\
\hline 45_EqualRemunWM_1 & ,710 & ,838 & \\
\hline 43_TrainingEducation_3 & 653 & ,808 & \\
\hline $40 \_$OccHealthSafety_4 & ,685 & ,806 & \\
\hline 34_Employment_4 & ,681 & ,776 & \\
\hline 31_Employment_1 & ,831 & & ,912 \\
\hline 32_Employment_2 & ,751 & & ,865 \\
\hline 33_Employment_3 & ,710 & & 817 \\
\hline \multicolumn{2}{|c|}{ Eigenvalues } & 3,694 & 2,109 \\
\hline \multicolumn{2}{|c|}{ Percentage of explained common variance for each factor } & 42,760 & 29,779 \\
\hline \multicolumn{2}{|c|}{ Percentage of explained common variance for the 2 factors } & \multicolumn{2}{|c|}{72,538} \\
\hline \multicolumn{2}{|c|}{ Cronbach Alpha for each factor } & 0,874 & 0,826 \\
\hline \multicolumn{2}{|l|}{ Total Cronbach Alpha } & \multicolumn{2}{|c|}{0,823} \\
\hline \multicolumn{2}{|l|}{ KMO index } & \multicolumn{2}{|c|}{0,801} \\
\hline \multicolumn{2}{|l|}{$\begin{array}{l}\text { Bartlett's test: } \\
\text { - } \\
\text { - } \\
\text { Chi-square } \\
\text { Ddl }\end{array}$} & \multicolumn{2}{|c|}{$\begin{array}{c}203,444 \\
28 \\
\text { Sig }=0,000\end{array}$} \\
\hline
\end{tabular}

\footnotetext{
${ }^{3}$ The criteria used to eliminate items were:

- Rejection of items whose factor score is less than 0.5;

- Rejection of isolated items.
} 
From table 7, we note that eight among the fifteen indicators proposed by the GRI were selected. Among the indicators selected, five are core indicators while there are additional indicators. Thus, the new factorial structure reveals two factorial axes. The first is composed of indicators 34, 39, 40, 43 and 45. It can be called Working conditions insofar as indicator 34 relates to Employment subcategory, indicators 39 and 40 refer to Occupational health and safety subcategory, indicator 43 refers to Training and education subcategory and indicator 45 reflects Equal remuneration for women and men subcategory. The second factorial axis includes indicators 31, 32 and 33. These three indicators belong to Employment subcategory. This axis can therefore be called Employment.

The results also show that the two factorial axes explain more than $70 \%$ of total variance. The internal consistency of the construct is good since the Cronbach's Alpha are all greater than 0.7. Thus, the sub-scale relating to the Labor Practices and Decent Work category is composed of eight indicators grouped into two categories: Working conditions and Employment.

\section{Sub-scale relating to Human Rights category}

To make sure that the collected data relating to Human Rights category are factorizable, we have firstly performed KMO index and Bartlett's tests. As shown in table 8, the KMO index seems satisfactory (0.914), thus this allows us to validate the factorial solution for the Human Rights category.

Table 8: Factor analysis of Human Rightsindicators

\begin{tabular}{|l|c|c|}
\hline \multirow{2}{*}{ Indicators } & \multirow{2}{*}{ Communalities } & Factors \\
\cline { 3 - 3 } & & $\mathbf{1}$ \\
\hline 53_HR_8 &, 819 &, 905 \\
\hline 49_HR_4 &, 791 &, 890 \\
\hline 54_HR_9 &, 786 &, 887 \\
\hline 55_HR_10 &, 775 &, 881 \\
\hline 51_HR_6 &, 740 &, 860 \\
\hline 52_HR_7 &, 731 &, 855 \\
\hline 48_HR_3 &, 708 &, 841 \\
\hline 47_HR_2 &, 687 &, 829 \\
\hline 56_HR_11 &, 643 &, 802 \\
\hline 46_HR_1 &, 597 &, 773 \\
\hline 50_HR_5 &, 581 &, 762 \\
\hline Eigenvalue & 7,859 \\
\hline Percentage of explained common variance & 71,444 \\
\hline Cronbach Alpha &, 959 \\
\hline KMO index & &, 914 \\
\hline Bartlett's test : & & 403,573 \\
$\bullet \quad$ Chi-square & & 55 \\
• Ddl & & Sig= \\
\hline
\end{tabular}

Secondly, we have analyzed the dimensionality of the construct. As shown in table 8, principal component analysis certifies the one-dimensional nature of this construct. We retain all the human rights indicators proposed by the GRI. These indicators are spread over a single factor entitled Human Rights. Thus, the new factor structure is composed of a single factor which explains more than $71 \%$ of the total variance. It has a high internal consistency reliability (Cronbach's Alpha equal to 0.959).

\section{Sub-scale relating to Society category}

Table 9 shows that the factorial solution relating to Society category is statistically good since it has a KMO index of around 0.697 and a significant Bartlett's test (0.000). Thus, we can confirm the factorizable nature of the data. 
Table 9: Factor analysis of Society indicators

\begin{tabular}{|c|c|c|c|c|}
\hline \multirow{2}{*}{ Indicators } & \multirow{2}{*}{ Communalities } & \multicolumn{3}{|c|}{ Factors } \\
\hline & & 1 & 2 & 3 \\
\hline 58_LocalCommunities_2 & ,898 & ,919 & & \\
\hline 59_LocalCommunities_3 & 800 & 843 & & \\
\hline 57_LocalCommunities_1 & ,713 & 826 & & \\
\hline 61_Corruption_2 & 921 & & ,934 & \\
\hline 62_Corruption_3 & ,916 & & ,909 & \\
\hline 60_Corruption_1 & 791 & & 713 & \\
\hline 64_PublicPolicy_2 & 910 & & & ,949 \\
\hline 63_PublicPolicy_1 & ,894 & & &, 896 \\
\hline \multicolumn{2}{|l|}{ Eigenvalues } & 4,094 & 1,699 & 1,051 \\
\hline \multicolumn{2}{|c|}{ Percentage of explained common variance for each factor } & 30,658 & 30,50 & 24,389 \\
\hline \multicolumn{2}{|c|}{ Percentage of explained common variance for the 3 factors } & \multicolumn{3}{|c|}{85,552} \\
\hline \multicolumn{2}{|c|}{ Cronbach Alpha for each factor } & 870 & ,913 & 870 \\
\hline \multicolumn{2}{|l|}{ Total Cronbach Alpha } & \multicolumn{3}{|c|}{,856 } \\
\hline \multicolumn{2}{|l|}{ KMO index } & \multicolumn{3}{|c|}{, 697} \\
\hline \multicolumn{2}{|l|}{$\begin{array}{l}\text { Bartlett's test: } \\
\text { • Chi-square } \\
\bullet \text { Ddl }\end{array}$} & \multicolumn{3}{|c|}{$\begin{array}{c}251,890 \\
28 \\
\text { Sig }=0,000\end{array}$} \\
\hline
\end{tabular}

According to table 9, the factorial solution is three-dimensional. Three factors summarize information about society. Indicators constituting the first factor synthesize $30.658 \%$ of total variance. The second factor explains $30.505 \%$ of total variance, while the third explains only $24.389 \%$ of this variance. Together, the three factors account for almost $85.552 \%$ of total variance.

Table 9 also provides an overview of the number of indicators related to identified factors. We note that two of the ten indicators contained in the questionnaire ( 8 core, 2 additional) were deleted ( 1 core and 1 additional). Indicators 57, 58 and 59, belonging to Local Communities subcategory, make up the first factorial axis, which can therefore be called Local Communities. The three indicators 60, 61 and 62, relating to Corruption subcategory, form the second factorial axis which can be, thus, entitled Corruption. The two indicators 63 and 64, belonging to Public Policy sub-category, form the third factor that can be referred to as Public Policy. In all, the results of the reliability analysis of society indicators reveal a Cronbach Alpha coefficient exceeding 0.8. Thus, these indicators appear reliable. As a result, the sub-scale relating to Society category is composed of eight indicators grouped into three factors: Local Communities, Corruption and Public Policy.

\section{Sub-scale relating to Product Responsibility category}

From the table 10, we note that the factorial solution is acceptable since the KMO index is of the order of 0.719 . The data are therefore factorizable and form a coherent whole.

Table10: Factor analysis of Product Responsibility indicators

\begin{tabular}{|c|c|c|c|c|}
\hline \multirow{2}{*}{ Indicators } & \multirow{2}{*}{ Communalities } & \multicolumn{3}{|c|}{ Factors } \\
\hline & & 1 & 2 & 3 \\
\hline 72_MarketCom_1 & ,771 & ,834 & & \\
\hline 73_MarketCom_2 & ,744 & ,827 & & \\
\hline 75_Compliance_1 & ,721 & ,775 & & \\
\hline 74_CustPrivacy_1 & ,781 & ,768 & & \\
\hline 70_ProdServLabeling_2 & ,888 & & ,877 & \\
\hline 71_ProdServLabeling_3 & ,771 & & ,828 & \\
\hline 69_ProdServLabeling_1 & ,798 & & ,760 & \\
\hline 68_CustHealthSafety_2 & ,891 & & & ,917 \\
\hline 67_CustHealthSafety_1 & ,866 & & & ,873 \\
\hline \multicolumn{2}{|c|}{ Eigenvalues } & 4,238 & 1,846 & 1,147 \\
\hline \multicolumn{2}{|c|}{ Percentage of explained common variance for each factor } & 30,276 & 25,473 & 24,601 \\
\hline \multicolumn{2}{|c|}{ Percentage of explained common variance for the 3 factors } & \multicolumn{3}{|c|}{80,350} \\
\hline \multicolumn{2}{|c|}{ Cronbach Alpha for each factor } & 0,835 & 0,856 & 0,929 \\
\hline \multicolumn{2}{|l|}{ Total Cronbach Alpha } & \multicolumn{3}{|c|}{0,857} \\
\hline \multicolumn{2}{|l|}{ KMO index } & \multicolumn{3}{|c|}{0,719} \\
\hline $\begin{array}{ll}\text { Bartlett's test : } \\
\text { - } & \text { Chi-square } \\
\text { - } & \text { Ddl }\end{array}$ & & \multicolumn{3}{|c|}{$\begin{array}{c}36 \\
\text { Sig }=0,000\end{array}$} \\
\hline
\end{tabular}


Table 10 reports the results of the exploratory factor analysis of indicators relating to Product Responsibility category. The factorial structure obtained is composed of three factors. The first represents $30.276 \%$ of the variance, the second counts for $25.473 \%$ while the third represents $24.601 \%$. According to the same table, on the first factor, we observe four indicators, on the second, three and on the third, two.The first factor may be titled Compliance with Product Rules and Regulations as it includes indicators 72 and 73 relating to Marketing Communications sub-category, indicator 74 relating to Customer Privacy sub-category and indicator 75 belonging to Compliance sub-category. The second factor may be called Product and Service Labeling as it consists of indicators 69, 70 and 71 belonging to Product and Service Labeling sub-category contained in the GRI guidelines. The last factor corresponds perfectly to Customer Health and Safety subcategory of the GRI guidelines since it includes indicators 67 and 68.We can also deduce that the Cronbach Alpha coefficient is satisfactory for each of the three factors, since it is greater than 0.7 , hence the reliability of the indicators relating to Product responsibility. As a result, the Product responsibility sub-scale is composed of nine indicators grouped into three factors: Compliance with Product Rules and Regulations, Product and Service Labeling, and Customer Health and Safety.

\section{Corporate governance scale}

From table 11, the values of the KMO index (0.740) and the Bartlett' test (0.000) lead to the acceptance of the results of the factorial analysis of the corporate governance indicators.

Table11 : Factor analysis of Corporate Governance indicators

\begin{tabular}{|c|c|c|c|c|}
\hline \multirow{2}{*}{ Indicators } & \multirow{2}{*}{ Communalities } & \multicolumn{3}{|c|}{ Factors } \\
\hline & & 1 & 2 & 3 \\
\hline 81_StructureConseil_6 & ,749 & ,861 & & \\
\hline 82_FonctConseil_1 & ,722 & ,810 & & \\
\hline 91_ComComptes_2 & 648 &, 773 & & \\
\hline 84_FonctConseil_3 &, 586 & 668 & & \\
\hline 76_StructureConseil_1 & 868 & & 889 & \\
\hline 77_StructureConseil_2 & 818 & & 871 & \\
\hline 78_StructureConseil_3 &, 764 & &, 793 & \\
\hline 92_StructProp_1 & 910 & & & ,925 \\
\hline 93_StructProp_2 & ,890 & & & ,924 \\
\hline \multicolumn{2}{|c|}{ Eigenvalues } & 4,081 & 1,718 & 1,156 \\
\hline \multicolumn{2}{|c|}{ Percentage of explained common variance for each factor } & 28,844 & 27,558 & 20,886 \\
\hline \multicolumn{2}{|c|}{ Percentage of explained common variance for the 3 factors } & \multicolumn{3}{|c|}{77,287} \\
\hline \multicolumn{2}{|c|}{ Cronbach Alpha for each factor } & 820 &, 880 & 840 \\
\hline \multicolumn{2}{|l|}{ Total Cronbach Alpha } & \multicolumn{3}{|c|}{845} \\
\hline \multicolumn{2}{|l|}{ KMO index } & \multicolumn{3}{|c|}{,740 } \\
\hline \multicolumn{2}{|l|}{$\begin{array}{l}\text { Bartlett's test : } \\
-\quad \text { Chi-square } \\
\text { - } \quad \text { Ddl }\end{array}$} & \multicolumn{3}{|c|}{$\begin{array}{c}274,811 \\
36 \\
.000\end{array}$} \\
\hline
\end{tabular}

The exploratory factor analysis of corporate governance indicators resulted in the elimination of ten indicators among the 19 included in the questionnaire. Eliminated indicators seem less appropriate for understanding the corporate governance dimension. As mentioned in table 11, the factorial solution obtained is composed of three factors. It explains $77.287 \%$ of total variance. According to the table 11, we note that the first factor is composed of four indicators related to three sub-categories namely indicator 81 which is part of Structure of the board of directors sub-category, indicators 82 and 84 which belong to Board of directors working sub-category and indicator 91 which refers to Statutory Auditorsub-category. Thus, this factor may be referred to as Various provisions concerning corporate governance.

Similarly, the matrix of structural coefficients proves that indicators 76,77 and 78 , belonging to Structure of the board of directors sub-category, are on the second factor that we can name Structure of the board of directors. Indicators 92 and 93, belonging to Company ownership structure sub-category, form the third factor that we can call Company ownership structure. In the same context of data cleansing, the results of the empirical verification of validity and reliability analyzes of the constructs demonstrate Cronbach's Alpha values greater than 0.7. They are of the order of 0.820 for the first factor, 0.880 for the second factor and 0.840 for the third one. 


\section{Discussion of results}

In terms of analyzing the perceived usefulness of ESG information indicators for investment decision, we have found that respondents favor corporate governance indicators and consider them as more useful than environmental and social ones. Indeed, subjected to a valuation in terms of utility, corporate governance indicators have benefited from an average score of 4.12 against an average score of 3.58 for environmental indicators and 3.47 for social ones. Thus, corporate governance dimension seems to be ahead of other ones in terms of relevance for investment allocation decision. This appears in line with the main results of the previous literature (Saghroun and Eglem, 2008; Eccles et al., 2011; de Zwaan et al., 2015; van Duuren et al., 2015) which has revealed the supremacy of corporate governance compared to the two other dimensions. In addition, environmental and social indicators seem to have almost the same utility with a slight dominance of the first ones. This seems in agreement with the results obtained by Eccles et al. (2011) who point out that the high interest in environmental indicators compared to social ones can be explained by the fact that the environmental implications are easier to quantify and to integrate into evaluation models. Regarding the exploratory factor analysis, the principal component analysis of environmental indicators generated two factorial axes relating respectively to Emissions and Waste. This result supports the results of the study of Chakroun (2012) which focused on the analysis of the perception of the usefulness of the voluntary disclosure by Tunisian financial analysts. Indeed, by conducting an exploratory factor analysis on a set of environmental and social indicators, she has obtained a factorial structure composed of two factorial axes: the first one relates to social information and the second one relates to environmental information. This last factor contains indicators related to corporate pollution abatement, to actions undertaken for management or recycling of products and waste, etc. On the other hand, our results contrast with those of Cauvin et al. (2006) who have analyzed the perception of non-financial communication by French companies. Indeed, following a principal component factor analysis on 11 themes related to non-financial disclosure, they noted that sustainable development theme, containing indicators such as emission of polluting substances, quantity of waste, etc., was excluded from the ranking.

The exploratory factor analysis carried out on the four categories of the social dimension gave rise to various factorial structures. The factorial structure relating to Labor Practices and Decent Workis based on two factors composed of eight indicators in total. The factorial structure relating to Human rights is composed of eleven indicators on a single factor. The factorial structure for Society contains eight indicators divided into three factors: Local Communities, Corruption and Public Policy. The factorial structure for Product Responsibility consists of nine indicators that form three factorial axes that refer to: Compliance with Product Rules and Regulations, Product and Service Labeling, and Customer Health and Safety. These results support those obtained by Chakroun (2012) who obtained a social information factor containing indicators relating to charitable donations, subsidies and financial aids; actions for the integration and employment of young people, women and disabled; sport and cultural activities for employees; employee absenteeism and number of strike days; etc.

The exploratory factor analysis carried out on corporate governance indicators have allowed us to select nine indicators divided into three factors, which relate respectively to Various provisions concerning corporate governance, Structure of the board of directors and to Company ownership structure. This result supports the results obtained in the study of Chakroun (2012) who has found a corporate governance factorial structure composed of two axes: the first one relates to the ownership structure. The second is related to the company's board of directors. The result we have reached seems also in line with the study by Cauvin et al. (2006) who have demonstrated that corporate communication topics are primarily directed to strategy, shareholders, governance and products.

\section{Conclusion}

Through this research, we have managed to determine a scale adapted to the information needs of Tunisian financial professionals with regard to Environmental, Social and Governance dimensions. This scale, composed of 53 indicators ${ }^{4}$, could eventually be used by companies to guide and improve their communication practices. Thus, collecting opinions and analyzing investor behaviors is likely to ensure the promotion of socially responsible practices of Tunisian companies.

\footnotetext{
${ }^{4}$ The selected indicators are presented in Appendix 1.
} 
In this sense, the latter have an interest in aligning themselves with the preferences of financial professionals, who are likely to influence the behavior of the investors in the stock market.

Our survey is also likely to promote the interest of GRI's guidelines in the business community and to encourage companies to adopt them to report on their sustainable development practices. Indeed, as Willis (2003) states, the GRI's guidelines appear to be an important tool for companies to communicate with their stakeholders about their performance and accountability beyond financial results.

We believe that our survey has led to some interesting results as much as ESG reporting practices need to be revised. Indeed, relevant ESG information must be provided and presented in an appropriate form and in line with investors' expectations in order to assist them in their investment decisions. In this context, our study has significant implications for accounting standard setters in so far as it can direct standardization efforts toward providing information that meets the decision-makers needs. This is likely to make ESG information specific and precise, not general and vague, and considered as an element of decoration in the annual report. However, given its exploratory nature, our study is subject to a number of limitations. Indeed, the small size of the sample raises the question of the generalization of the results obtained. Similarly, we think that the length of the questionnaire was a source of demotivation for respondents. In addition, we were unable to conduct random sampling because we did not have a survey database containing the population's email addresses (Blais and Durand, 2009).

Finally, we propose to reproduce this research in different contexts to test the validity of the results obtained. Also, a more detailed study of the ESG criteria proves to be essential in order to develop more refined knowledge. A comparative analysis can likewise be done. Other stakeholders may be solicited for similar studies.

\section{Bibliography}

Adams, C. A. and Frost, G. R. (2008), "Integrating sustainability reporting into management practices", Accounting Forum, Vol. 32 No. 4, pp. 288-302.

Ben Rhouma, A., Demolli, E., Moisson, J.Y. and Boyer, T. (2011), “Transition démocratique et reporting environnemental, social et de gouvernance (ESG) en Tunisie",Maghreb-Machrek, Vol. 3, pp. 43-64.

Berry, T. C. and Junkus, J. C. (2013), "Socially Responsible Investing: An Investor Perspective”, Journal of Business Ethics, Vol.112 No. 4, pp. 707-720.

Blais, A. and Durand, C. (2009),"Le sondage", InB. Gauthier, Recherche sociale : de la problématique à la collecte des données, pp. 445- 487. Presses de l'Université du Québec.

Cauvin, E., Decock-Good, C. and Bescos, P.L. (2006),"La perception des entreprises françaises en matière de diffusion d'informations non financières : une enquête par questionnaire", Comptabilité-Contrôle-Audit, Vol. 12 No.2, pp. 17-42.

Chakroun, R. (2012), “La perception de l'utilité de l'information volontaire dans les rapports annuels par les analystes financiers tunisiens", Recherches en Comptabilité et Finance, Vol. 8, pp. 35-60.

Chan, C. and Milne, M. (1999), "Investor reactions to corporate environmental saints and sinners: an experimental analysis", Accountingand Business Research, Vol. 29 No. 4, pp. 265-279.

Chang, R. D. and Wei, J.T. (2011), "Effects of governance on investment decisions and perceptions of reporting credibility: Investment experience of Taiwanese individual investors", Asia Pac J Manag, Vol. 28, pp. 139-155.

Chen, K. C. W., Chen, Z. and Wei, K. C. J. (2003). "Disclosure, Corporate Governance, and the Cost of Equity Capital: Evidence from Asia's Emerging Markets", In Proceedings of the 3rd. Asian Corporate Governance Conference, Korea University and the Hong Kong University of Science and Technology.

Cheng, M.M., Green, W. T. and Chi Wa Ko, J. (2015), "The impact of strategic relevance and assurance of sustainability indicators on investors' decisions”, Auditing: A Journal of Practice \& Theory, Vol. 34 No. 1, pp. 131-162.

Cohen, J., Holder-Webb, L., Nath, L. and Wood, D. (2010), "Retail Investors' Perceptions of the DecisionUsefulness of Economic Performance, Governance, and Corporate Social Responsibility Disclosures",Behavioral Research in Accounting, Vol. 23 No. 1, pp. 109-129.

De Zwaan, L., Brimble, M. and Stewart, J. (2015),"Member perceptions of ESG investing through superannuation”, Sustainability Accounting, Management and Policy Journal, Vol. 6 No. 1, pp. 79 - 102. 
Deegan, C. and Rankin, M. (1997), "The materiality of environmental information to users of annual reports",Accounting, Auditing and Accountability Journal, Vol. 10 No. 4, pp. 562-583.

Eccles, R.G., Serafeim, G. and Krzus, M.P. (2011),"Market Interest in Nonfinancial Information", Journal of Applied Corporate Finance, Vol. 23 No. 4, pp. 113-128.

Edmans, A. (2009), "Does the Stock Market Fully Value Intangible, Employee Satisfaction and Equity Prices?",ssrn.com.

Evrard, Y., Pras, B. and Roux, E. (2003),Market : Etudes et recherches en marketing (3 ${ }^{\text {ème }}$ édition). Paris : Dunod.

Frimousse, S., Mansouri, N. and Peretti, J.M. (2006),"La performance sociale et la légitimité institutionnelle", Papier présenté au $27^{\text {ème }}$ Congrès de l'Association Francophone de Comptabilité, Tunis.

Galanti, S. (2006), "Les analystes financiers comme intermédiaires en information”, Thèse de doctorat en sciences économiques, Université Paris X, Nanterre.

Galbreath, J. 2013. "ESG in focus: the Australian evidence", Journal of Business Ethics, Vol. 118 No. 3, pp. 529541.

Global Reporting Initiative (GRI). Versions : 2002, 2003, 2006, Lignes directrices pour le reporting développement durable. (www. globalreporting.org/guidelines).

Guidry, R. P. and Patten D. M. (2010),"Market reactions to the first-time issuance of corporate sustainability reports: Evidence that quality matters", Sustainability Accounting, Management and Policy Journal, Vol. 1 No. 1 , pp. $33-50$.

Henderson, S., Smith, A. and Gordon, R. (2006), “The GRI Guidelines- their use by New Zealand organizations”, Chartered Accountants Journal, pp. 69-73.

Holm, C. and Rikhardsson, P. (2008),"Experienced and Novice Investors: Does Environmental Information Influence Investment Allocation Decisions?”,European Accounting Review, Vol. 17 No. 3, pp. 537-557.

Ioannou, I. and Serafeim, G. (2010), "The Impact of Corporate Social Responsibility on Investment Recommendations", Best Paper Proceedings of the Academy of Management, Annual Meeting.

Jaggi, B. and Zhao, R. (1996), "Environmental performance and reporting: perceptions of managers and accounting professional in Hong Kong”, The international Journal of Accounting, Vol. 31 No. 3, pp. 333346.

Khemakhem, H. and Turki, H. (2007), "L'information environnementale et la prise de décision d'investissement :Étude empirique dans le cadre d'un marché émergent", Papier présenté au $28^{\text {ème }}$ congrès annuel de l'Association Francophone de Comptabilité, Poitiers.

Khemir, S. and Baccouche, C. (2010), "Analysis of the determinants of corporate social responsibility disclosure in the annual reports of Tunisian listed firms", In Research in Accounting in Emerging Economies, Vol. 10, pp. 119-144.

Khemir, S. (2014), “Perception, utilité et influence de l'information Environnementale, Sociale et de Gouvernance sur la prise de décision d'investissement", Thèse de doctorat en sciences de gestion, Université Toulouse 1 Capitole.

KPMG. (2015),“Currents of change”, The KPMG International Survey of Corporate Responsibility Reporting. kpmg.com

Krüger, P. (2009), "Stakeholder information and shareholder value", Working paper. Toulouse School of Economics.

Lorraine, N. H. J., Collison, D. J. and Power, D. M. (2004), "An analysis of the stock market impact of environmental performance information”, Accounting Forum, Vol. 28, pp. 7-26.

McGraw, P. and Katsouras, A. (2010), "A review and analysis of CSR practices in Australian second tier private sector firms", Employment relations record, Vol. 10 No. 1, pp. 1-24

Milne, M. and Chan, C. (1999), "Narrative social disclosures: how much of a difference do they make to investor decision-making”,British Accounting Review, Vol. 31, pp. 439-457.

Quairel, F. (2004), "Responsable mais pas comptable : analyse de la normalisation des rapports environnementaux et sociaux",Comptabilité-Contrôle-Audit, Vol. 10 No. 1, pp. 7-36.

Rikhardsson, P. and Holm, C. (2008), "The Effect of Environmental Information in Investment Allocation Decisions-an Experimental Study", Business Strategy and the Environment, Vol. 17, pp. 382-397.

Saghroun, J. and Eglem, J.Y. (2008), “A la recherche de la performance globale de l'entreprise : La perception des analystes financiers ”,Comptabilité-Contrôle- Audit, Vol. 14 No.1, pp. 93-118. 
Sahut, J.-M. and Pasquini-Descomps, H. (2015), "ESG Impact on Market Performance of Firms: International Evidence. Management International", Vol. 19 No. 2, pp. 40-63.

Staubus, G. J. (1999), The Decision-Usefulness Theory of Accounting: A Limited History. New York: Garland.

Teoh, H.Y. and Shiu, G.Y., (1990), "Attitudes towards corporate social responsibility and perceived importance of social responsibility information characteristics in a decision context", Journal of Business Ethics, Vol. 9, pp. 71-77.

Thompson, P. and Cowton, C. J. (2004), "Bringing the environment into bank lending: implications for environmental reporting", The British Accounting Review, Vol. 36, pp. 197-218.

Van der Laan Smith, J., Adhikari, A., Tondkar, R. H. and Andrews, R. L. (2010), "The impact of corporate social disclosure on investment behaviour: A cross-national study", J. Account. Public Policy, Vol. 29, pp. 177-192.

Van Duuren, E., Plantinga, A. and Scholtens, B. (2015), "ESG Integration and the Investment Management Process: Fundamental Investing Reinvented", Journal of Business Ethics, pp.1-9.

Vintilă, G. and Gherghina, S. C. (2012), "An Empirical Examination of the Relationship between Corporate Governance Ratings and Listed Companies' Performance”, International Journal of Business and Management, Vol. 7 No 22, pp. 46-61.

Wahba, H. (2008), "Does the market value corporate environmental responsibility? An empirical examination",Corporate Social Responsibility and Environmental Management, Vol. 15 No 2, pp. 89-99.

Whitehouse, L. (2006), "Corporate Social Responsibility: Views from the Frontline", Journal of Business Ethics, Vol. 63, pp. 279-296.

Willis, C.A. (2003),"The role of the Global Reporting Initiative's Sustainability Reporting Guidelines in the Social Screening of Investments", Journal of Business Ethics, Vol. 43, pp. 233-237.

Xu, X. D., Zeng, S. X. and Tam, C. M. (2012), "Stock Market's Reaction to Disclosure of Environmental Violations: Evidence from China", Journal of Business Ethics, Vol. 10 No. 7, pp. 227-237.

Zramdini, O. and Fedhila, H. (2003), "La perception de l'utilité de l'information à caractère social et environnemental pour la décision d'octroi de crédits : Cas des banques commerciales tunisiennes", $L a$ Revue du Financier, Complément $\mathrm{N}^{\circ} 141$.

Zramdini, O. (2011), "Étude des déterminants de la communication environnementale des entreprises : cas de la Tunisie et du Maroc", Thèse de doctorat en sciences de gestion, Université Franche-Comté Besançon.

\section{Appendix 1}

\section{Summary table of selected indicators}

\begin{tabular}{|l|l|l|}
\hline Environmental dimension & Nature & Factor \\
\hline $\begin{array}{l}\text { 16- Total direct and indirect greenhouse gas emissions by weight. } \\
\text { 18- Initiatives to reduce greenhouse gas emissions and reductions achieved. }\end{array}$ & Core & F1 \\
19- Emissions of ozone-depleting substances by weight. & F1 \\
17- Other relevant indirect greenhouse gas emissions by weight. & Core & F1 \\
20- NO, SO, and other significant air emissions by type and weight. & Core & F1 \\
24-Weight of transported, imported, exported, or treated waste deemed hazardous under \\
the terms of the Basel Convention Annex I, II, III, and VIII, and percentage of \\
transported waste shipped internationally. \\
$\begin{array}{l}\text { 25- Identity, size, protected status, and biodiversity value of water bodies and related } \\
\text { habitats significantly affected by the reporting organization's discharges of water and } \\
\text { runoff. }\end{array}$ & Add \\
22- Total weight of waste by type and disposal method. & F2 \\
\hline \begin{tabular}{l} 
Societal dimension \\
\multicolumn{1}{|c|}{ Labor Practices and Decent Work }
\end{tabular} & Core & F2 \\
\hline $\begin{array}{l}\text { 39-Education, training, counseling, prevention, and risk-control programs in place to } \\
\text { assist workforce members, their families, or community members regarding serious } \\
\text { diseases. } \\
\text { 45-Ratio of basic salary and remuneration of women to men by employee category, by } \\
\text { significant locations of operation. }\end{array}$ & Core & F1 \\
\hline
\end{tabular}




\begin{tabular}{|c|c|c|}
\hline $\begin{array}{l}\text { 43-Percentage of employees receiving regular performance and career development } \\
\text { reviews, by gender. }\end{array}$ & Add & $\mathrm{F} 1$ \\
\hline 40-Health and safety topics covered in formal agreements with trade unions. & Add & F1 \\
\hline 34- Return to work and retention rates after parental leave, by gender. & Core & $\mathrm{F} 1$ \\
\hline $\begin{array}{l}\text { 31-Total workforce by employment type, employment contract, and region, broken down } \\
\text { by gender }\end{array}$ & Core & $\mathrm{F} 2$ \\
\hline $\begin{array}{l}\text { 32-Total number and rate of new employee hires and employee turnover by age group, } \\
\text { gender, and region. }\end{array}$ & Core & $\mathrm{F} 2$ \\
\hline $\begin{array}{l}\text { 33-Benefits provided to full-time employees that are not provided to temporary or part- } \\
\text { time employees, by significant locations of operation. }\end{array}$ & Add & $\mathrm{F} 2$ \\
\hline \multicolumn{3}{|l|}{ HumanRights } \\
\hline $\begin{array}{l}\text { 53-Percentage of security personnel trained in the organization's policies or procedures } \\
\text { concerning aspects of human rights that are relevant to operations. }\end{array}$ & Add & F1 \\
\hline 49-Total number of incidents of discrimination and corrective actions taken. & Core & F1 \\
\hline $\begin{array}{l}\text { 54- Total number of incidents of violations involving rights of indigenous people and } \\
\text { actions taken. }\end{array}$ & Add & F1 \\
\hline $\begin{array}{l}\text { 55-Percentage and total number of operations that have been subject to human rights } \\
\text { reviews and/or impact assessments. }\end{array}$ & Core & F1 \\
\hline $\begin{array}{l}\text { 51- Operations and significant suppliers identified as having significant risk for incidents } \\
\text { of child labor, and measures taken to contribute to the effective abolition of child labor. }\end{array}$ & Core & F1 \\
\hline $\begin{array}{l}\text { 52- Operations and significant suppliers identified as having significant risk for incidents } \\
\text { of forced or compulsory labor, and measures to contribute to the elimination of all forms } \\
\text { of forced or compulsory labor. }\end{array}$ & Core & F1 \\
\hline $\begin{array}{l}\text { 48- Total hours of employee training on policies and procedures concerning aspects of } \\
\text { human rights that are relevant to operations, including the percentage of employees } \\
\text { trained. }\end{array}$ & Core & F1 \\
\hline $\begin{array}{l}\text { 47- Percentage of significant suppliers, contractors and other business partners that have } \\
\text { undergone human rights screening, and actions taken. }\end{array}$ & Core & F1 \\
\hline $\begin{array}{l}\text { 56- Number of grievances related to human rights filed, addressed and resolved through } \\
\text { formal grievance mechanisms. }\end{array}$ & Core & F1 \\
\hline $\begin{array}{l}\text { 46-Percentage and total number of significant investment agreements and contracts that } \\
\text { include clauses incorporating human rights concerns, or that have undergone human } \\
\text { rights screening. }\end{array}$ & Add & F1 \\
\hline $\begin{array}{l}\text { 50-Operations and significant suppliers identified in which the right to exercise freedom } \\
\text { of association and collective bargaining may be violated or at significant risk, and } \\
\text { actions taken to support these rights. }\end{array}$ & Core & F1 \\
\hline \multicolumn{3}{|l|}{ - Society } \\
\hline $\begin{array}{l}\text { 58- Operations with significant potential or actual negative impacts on local } \\
\text { communities. }\end{array}$ & Core & F1 \\
\hline $\begin{array}{l}\text { 59- Prevention and mitigation measures implemented in operations with significant } \\
\text { potential or actual negative impacts on local communities. }\end{array}$ & Core & F1 \\
\hline $\begin{array}{l}\text { 57- Percentage of operations with implemented local community engagement, impact } \\
\text { assessments, and development programs. }\end{array}$ & Core & F1 \\
\hline $\begin{array}{l}\text { 61-Percentage of employees trained in organization's anti-corruption policies and } \\
\text { procedures. }\end{array}$ & Core & $\mathrm{F} 2$ \\
\hline 62-Actions taken in response to incidents of corruption. & Core & $\mathrm{F} 2$ \\
\hline $\begin{array}{l}\text { 60- Percentage and total number of business units analyzed for risks related to } \\
\text { corruption. }\end{array}$ & Core & $\mathrm{F} 2$ \\
\hline $\begin{array}{l}\text { 64- Total value of financial and in-kind contributions to political parties, politicians, and } \\
\text { related institutions by country. }\end{array}$ & Add & F3 \\
\hline $\begin{array}{l}63 \text { - Public policy positions and participation in public policy development and } \\
\text { lobbying. }\end{array}$ & Core & F3 \\
\hline - $\quad$ Product Responsibility & & \\
\hline
\end{tabular}


72- Programs for adherence to laws, standards, and voluntary codes related to marketing communications, including advertising, promotion, and sponsorship.

73-Total number of incidents of non-compliance with regulations and voluntary codes concerning marketing communications, including advertising, promotion, and sponsorship by type of outcomes.

75- Monetary value of significant fines for noncompliance with laws and regulations concerning the provision and use of products and services.

74-Total number of substantiated complaints regarding breaches of customer privacy and losses of customer data.

70- Total number of incidents of non-compliance with regulations and voluntary codes concerning product and service information and labeling, by type of outcomes.

71- Practices related to customer satisfaction, including results of surveys measuring customer satisfaction.

69- Type of product and service information required by procedures, and percentage of significant products and services subject to such information requirements.

68- Total number of incidents of non-compliance with regulations and voluntary codes concerning health and safety impacts of products and services during their life cycle, by type of outcomes.

67-Life cycle stages in which health and safety impacts of products and services are assessed for improvement, and percentage of significant products and services categories subject to such procedures

\section{Corporate gouvernance dimension}

81-Percentage of Independent Directors in Control Committees and Standing Audit Committees

82-Number of annual meetings of the board of directors

91- Existence of a co-audit

84- Process put in place by the board of directors to avoid conflicts of interest

76-Size of the board of directors

77-Mandate's duration of members of the board of directors

78-Number of independent and / or non-executive directors on the board of directors

92-Dispersion / Concentration of capital

93- Nature of the shareholding

\begin{tabular}{|l|l|} 
Core & F1 \\
Add & F1 \\
Core & F1 \\
Add & F1 \\
Add & F2 \\
Add & F2 \\
Core & F2 \\
Add & F3 \\
Core & F3 \\
& F2 \\
\hline & F1 \\
& F1 \\
& F1 \\
\hline & \\
\hline
\end{tabular}

